\title{
Anti-Proliferative Effect of Ethanol on Normal and Cancer Cells
}

Myung-Ju Oh', Jihyun $\mathrm{Kim}^{2}$, Su-Hyun Park'2, Young-Hwa Jeong', Kun Wang ${ }^{3}$, Byung-Wook Cho ${ }^{3}$ and Byung $\mathrm{H}$. Jhun ${ }^{2}$ *

${ }^{1}$ Division of Cinical Trials Management, Bureau of Risk Prevention Policy, Korea Food and Drug Administration, Cheongwon-gun, Chungbuk 363-951, Korea

${ }^{2}$ Department of Nanomedical Engineering, Pusan National University, Miryang 727-706, Korea

${ }^{3}$ Department of Animal Sciences, Pusan National University, Miryang 727-706, Korea

Received February 17, 2012 /Revised March 21, 2012 /Accepted March 22, 2012

\begin{abstract}
Ethanol is known as being carcinogenic to humans. In addition, the anti-proliferative effects of ethanol have been described for a variety of tissues and cells. In this study, we investigated the anti-proliferative effects of ethanol on various cancer cells, particularly on oncogenic rastransformed or -injected cells. Ethanol treatment inhibited the cell proliferation of normal control cells, but did not suppress the proliferation of various cancer cells and oncogenic rastransformed cells. Furthermore, ethanol treatment did not interfere with DNA synthesis, which was induced by microinjecting the oncogenic H-Ras ${ }^{\mathrm{V} 12}$ protein. The anti-proliferative effect of ethanol was rescued by antioxidants, such as $N$-acetylcysteine and 4-methlpyrazole. These results suggest that ethanol cytotoxicity is exerted through free radical formation, and that the anti-proliferative action site of ethanol cytotoxicity either lies upstream, or is independent of Ras.
\end{abstract}

Key words : Ethanol, cell proliferation, Ras, microinjection, antioxidant

\section{서 론}

$\mathrm{WHO}$ 의 보고에 따르면 인간암발생의 $3.6 \%$ 가 에탄올에 기 인한다고 발표하였고, 1988년부터 International Agency for Research on Cancer (IARC)는 에탄올을 carcinogen으로 분류 하였고, 그 뒤 동물에서도 carcinogen실험 결과를 보고하였다 [11,21]. 에탄올에 의해 주로 발생하는 암으로는 구강암, 인후 암, 후두암, 간암, 대장암, 유방암 등이 있는 것으로 알려져 있다 [1,2]. 대장암과 유방암은 이전에 알려진 것보다 훨씬 높 은 빈도로 에탄올 섭취와 연관이 있는 것으로 밝혀졌다.

에탄올에 연관된 암 발생의 genetic susceptibility연구에서 에탄올 대사, folate 대사, DNA repair에 관련된 유전자들의 유전적 다양성이 알려져 있다[1]. 그 중 alcohol dehydrogenase와 aldehyde dehydrogenase의 유전적 다형성이 일부 암 발생에 관련이 있는 것으로 보고되었으나, 에탄올의 대사에 관련한 CYP2E1 등은 관련이 없는 것으로 알려져 있다[3,27]. 에탄올에 의한 암발생의 분자기전은 다양하다. 최근 에탄올 의 장기 투여에 의해 ras유전자의 변이가 발생하는 것이 보고 되었다[6,12]. ras 유전자는 세포증식, 세포분화, 세포 골격변화 를 포함하는 다양한 세포 활동에 관여한다[20]. 이러한 ras의 과발현이나 변이는 여러 종류의 인간 암에서 $30 \%$ 의 빈도로 발견된다. 특히 ras 암유전자의 12 번, 13 번, 61 번 아미노산 위
치에서의 변이가 잘 발견된다. 발암원성 H-ras 암유전자에 의 해 형질전환된 쥐에 에탄올을 투여했을 시에 표준 group에 비해 높은 빈도의 종양이 발생함을 보고했다[5]. 따라서 에탄 올이 발암원성 $r a s$ 유전자에 의한 종양 발생에 중요한 역할을 할 수 있다.

에탄올에 의한 세포증식억제 작용은 췌장 랑게르한스 세포 증식[18], 골수세포 증식 및 분화[25], T-cell 증식[8]에서 보여 지고, Smooth muscle cell 분화[17], 골세포 분화[9], 신경조직 형성[16]와 같은 정상적인 세포작용도 억제하는 것이 보고되 었다. 또한 에탄올은 간절제술이나 간의 화학적 손상 후에 회 복을 방해하는 것으로 알려져 있다[24,29]. 이러한 에탄올의 세포증식이나 세포 회복에 대한 억제효과는 잘 알려져 있으 나, 암세포의 세포증식억제 효과에 대해서는 잘 알려져 있지 않다. 본 연구에서 에탄올의 여러 조직별 정상세포와 암세포 의 세포증식억제 효과를 비교하였고, 발암원성 $\mathrm{H}-\mathrm{raS}^{\mathrm{V} 12}$ 와 발 암원성K- $\mathrm{ras}^{\mathrm{V} 12}$ 에 의해 형질 전환된 세포에서 세포증식과 DNA 합성을 관찰함으로써 에탄올에 의한 세포증식억제효과 가 발암원성ras 유전자에 의한 암발생에는 어떤 영향을 미치 는지를 조사하였다. 이번 실험결과에서 우리는 에탄올에 의해 세포증식 억제효과가 일반적인 정상세포에서는 작동하나 암 세포 특히 ras 유전자 변이에 의한 세포의 증식에는 영향이 없음을 알 수 있었다.

\footnotetext{
${ }^{*}$ Corresponding author Tel : +82-55-350-5291, Fax : +82-55-350-5653

E-mail : bjhun@pusan.ac.kr
} 


\section{재료 및 방법}

\section{세포주와 재료}

정상세포주와 암세포주들은 각 조직별로 American Tissue Culture Collection (ATCC) (Manassas, VA)에서 구입하였고, $\mathrm{ATCC}$ 에서 권하는 방법대로 각 배지에 배양하였다. H-ras ${ }^{V 12}$ transformed Rat-2세포와 K-ras ${ }^{V 12}$-transformed Rat-2세포 및 대조군 Rat-2 세포는 Dr. J.K Pai (Merck/Schering-Plough, Whitehouse Station, NJ)로부터 제공받았고, 이는 $10 \%$ fetal bovine serum이 포함된 DMEM 배지에서 유지하였다. Bromodeoxyuridine $(\mathrm{BrdU})$ 과 mouse anti-BrdU antibody는 GE Healthcare Life Science (Piscataway, NJ)의 제품을 사용하 였고, FITC-conjugated anti-rat IgG antibody는 Jackson Lab (Bar Harbor, ME)에서 제공받았다. 다른 모든 시약들은 Sigma-Aldrich (Germany)에서 구입하였다.

\section{에탄올에 의한 세포증식 효과 측정}

각 세포들은 여러 농도의 에탄올에서 $37^{\circ} \mathrm{C}$ 에서 배양하였 고, 에탄올을 함유한 배지는 매일 교환하였다. 에탄올의 증발 을 최소화하기 위해서 parafilm으로 밀봉하였고, 이러한 처 리는 원래의 세포증식이나 세포 morphology를 방해하지 않 았다. 에타올을 처리한 세포는 trypsin으로 분리하고, 세포수 는 tryphan blue staining을 통해 세포 숫자를 계산하였다. 항산화제인 $N$-acetylcysteine $(1 \mathrm{mM}), 4$-methylpyrazole $(1$ $\mathrm{mM})$, vitamin $\mathrm{E}(25 \mathrm{mM})$, trolox $(0.2 \mathrm{mM})$ 는 에탄올 처리 1 시간 전에 처리하였고, 그 후에 에탄올 $(100 \mathrm{mM})$ 을 처리하 고 세포를 배양하였다. 에탄올에 의한 세포증식억제효과에 대한 항산화제의 효과를 알아보는 실험은 위와 같은 방법으 로 진행하였다.

\section{세포미세주사 및 $\mathrm{BrdU}$ 면역형광법을 이용한 DNA 합성 실험} 세포미세주사법을 이용하여 발암원성 Ras에 의한 DNA 합 성에 대한 에탄올의영향을 조사하기 위해 oncogenic H-Ras ${ }^{\mathrm{V} 12}$ 를 정상유방 세포주인 MCF-12A세포에 주사하여 DNA합성은 아래와 같이 측정하였다 [19]. 요약하면, MCF-12A세포를 coverslip 위에서 배양한 후, serum-free DMEM으로 배양하여 세 포주기를 정지시켰다. 이 세포를 미세주사하기 에탄올(100 $\mathrm{mM})$ 으로 4 시간동안 처리하였다. 그 후에 발암원성 $\mathrm{H}-\mathrm{Ras}^{\mathrm{V} 12}$ protein $(2 \mathrm{mg} / \mathrm{ml})$ 를 rat $\mathrm{IgG}(4 \mathrm{mg} / \mathrm{ml})$ 과 함께 MCF- $12 \mathrm{~A}$ 세 포에 미세주사하였다. MCF-12A 세포를 키운 3개의 coverslip 에 coverslip당 평균 200개의 세포에 미세주사하였고, 이를 두 번 반복하였다. 따라서 미세주사 결과는 평균 1,200 개의 세포 에서 나온 결과이다. 미세주사한 세포의 생존율은 $90 \%$ 이상이 었다. 미세주사된 세포는 $\mathrm{BrdU}$ 를 세포 배지에 투입하여 $37^{\circ} \mathrm{C}$ 에서 16 시간 동안 배양하고, 이를 $90 \%$ 에탄올로 세포를 고정하 였다. 미세주사된 세포는 anti-BrdU antibody로 면역염색하
고, 그 후에 TRITC-conjugated anti-mouse igG antibody로 처 리되었다. 미세주사된 세포를 찾기위해 세포에 같이 주사된 rat IgG를 FITC-labeled anti-rat IgG antibody로 염색하였다. 미세주사된 세포는 세포질의 FITC 염색으로 확인되고, DNA 합성은 핵의 TRITC 염색으로 확인되며, 에탄올이 발암원성 Ras에 의한 DNA 합성 유도에 대한 영향을 형광현미경으로 그 결과를 조사하였다.

\section{세포내 활성산소의 측정}

세포내 활성산소양의 측정은 2,7-dichlorohydrofluerescence $\left(\mathrm{H}_{2} \mathrm{DCFDA}\right)$ 가 형광을 나타내는 2,7-dichlorofluorescein (DCF)로 산화되는 측정법에 의해 조사하였다 [14]. $100 \%$ 에탄 올에 $\mathrm{H}_{2} \mathrm{DCFDA}$ stock 용액 $(12.5 \mathrm{mM})$ 을 만들어 $-20^{\circ} \mathrm{C}$ 에 보관 하였고, $25 \mu \mathrm{M}$ 의 working 용액을 사용하였다. DCF의 형광광 도는 형광마이크로 리더(Bio-Tek Instruments, Winooki, VT, USA)를 사용하여 excitation 파장은 $485 \mathrm{~nm}$, emission 파장은 $530 \mathrm{~nm}$ 에서 측정하였다.

\section{통계처리}

실험에서 얻어진 결과치는 ANOVA 검정에 의한 평균치와 표준오차(means $\pm \mathrm{SE}$ )로 표시하였으며, 각 실험군 간의 유의성 검정은 Fischer's Protected LSD post-hoc test로 하였다.

\section{결 과}

\section{정상세포와 암세포의 세포증식에 대한 에탄올의 억제 효과} 비교

다양한 조직 유래의 정상세포주와 암세포주를 배양하여 에 탄올에 의한 세포증식억제 효과를 조사하였다(Fig. 1). 사용한 세포주를 분류하면, 유방세포주로는 사람의 정상세포인 MCF-12A와 대표적인 유방암세포 연구에 사용되는 MCF-7, SK-BR-3, T-47D에서의 에탄올의 효과를 비교하였고, 간세포 는 정상세포인 Chang세포주와 간암세포인 HepG2세포를 비 교하였고, 췌장세포로는 정상세포인 HIT-T12와 암세포인 $\mathrm{MIA} \mathrm{PaCa}-2$ 를 비교하였고, 신경세포에서는 정상세포인 RSC96과 암세포인 PC-12 및 Neuro-2a를 비교하였고, 폐세포 로는 정상세포인 WI-38과 암세포인 HT-1080 및 A549 세포를 비교하였다. 그 결과, 공통적으로 정상세포에서는 에탄올에 의해 세포증식이 현저하게 억제되었고, 반면 암세포에서는 그 효과가 없음을 알 수 있었다. 또한 일반적인 세포 연구에 많이 사용되는 신장 유래 세포인 CV-1, 근육세포인 L6, 지방세포인 3T3-L1에서도 동일하게 에탄올에 의해 세포성장이 억제 되었 다. 그 억제 정도는 조직별로 차이가 있으며, 신경세포에서 현저한 억제 효과가 관찰되었고, 유방세포에서는 그 효과 다 소 약함을 알 수 있었다. 
(A) Breast

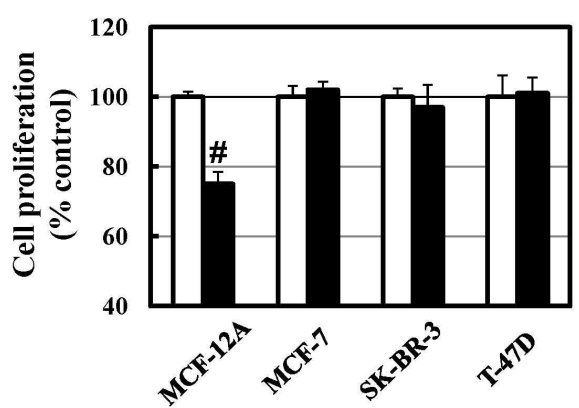

(C) Pancreas

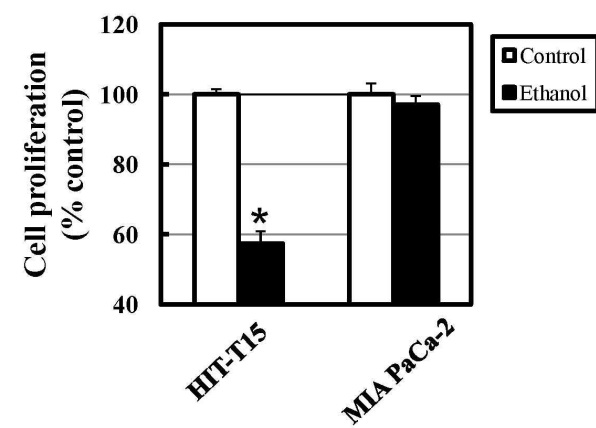

(E) Lung

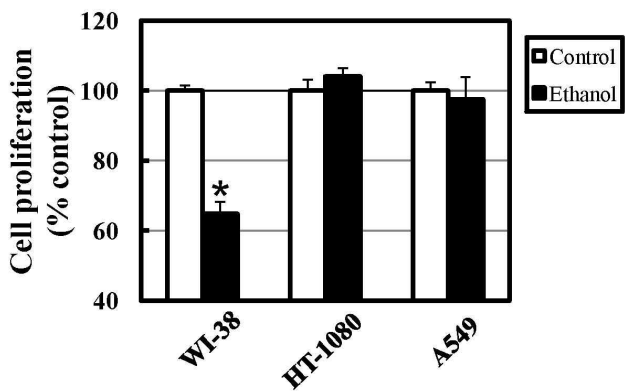

(B) Liver
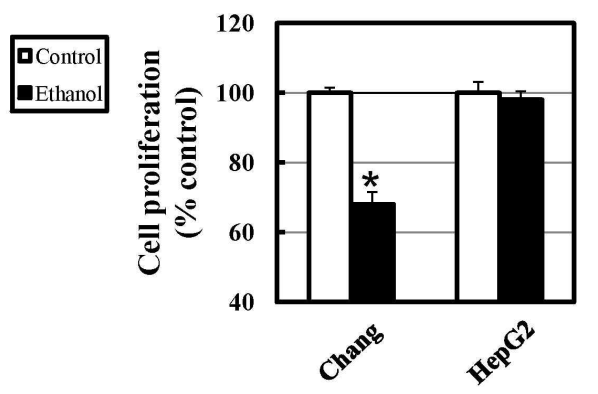

(D) Nerve

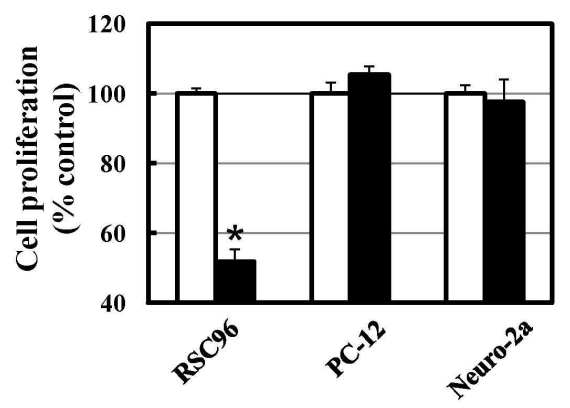

(F) Other normal cells

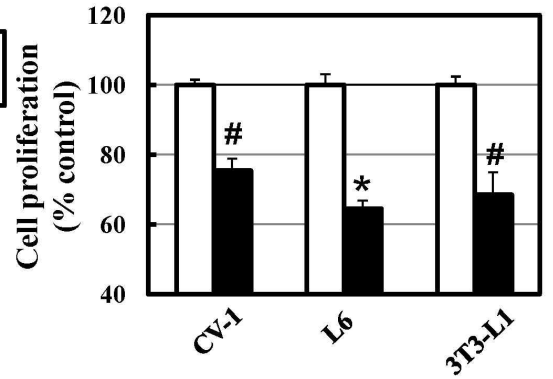

Fig. 1. Effect of ethanol on the proliferation of normal cells and cancer cells. Normal cells and cancer cells $\left(4 \times 10^{4}\right.$ cell/well) were plated and treated with a medium containing ethanol $(100 \mathrm{mM})$ for 3 days. The plates were tightly wrapped with parafilm and the media were refreshed every day. The number of cells was counted as described in the "Materials and Method" section. The data represent the mean number of cells from two experiments. Each experiment was performed in triplicate. The significance was determined by the ANOVA test $\left({ }^{\#} p<0.05\right.$ and ${ }^{*} p<0.01$ vs. untreated control).

발암원성 $\mathrm{H}-\mathrm{ras}$ 와 $\mathrm{K}$-ras에 의해 형질전환된 세포에서의 에탄올의 세포증식 억제 효과

Fig. 1의 실험에서 사용한 암세포는 다양한 암유전자의 변 이로 형질전환된 세포이므로 세포내의 어떤 유전자 변이로 인한 것인지, 세포증식 신호전달 과정의 어떤 경로가 에탄올 의 세포증식 억제효과를 상쇄하는지 알 수 없으므로 이를 이 해하는 것은 중요하다. 따라서 본 연구에서 정상적인 Rat-2 세포에 발암원성 H-ras ${ }^{\mathrm{V} 12}$ 나 K- $\mathrm{ras}^{\mathrm{V} 12}$ 로 형질전환 시킨 세포에 서 에탄올의 세포증식 억제 효과를 조사하여 Ras단백질과의
상호관계를 알아보았다. Fig. 2에서 보이는 바와 같이 에탄올 은 parental Rat-2 세포의 증식을 농도의존적으로 억제했고, 이를 다른 세포주 연구와 비교해볼 때 유의성을 가진 것을 알 수 있었다. 반대로 형질변환된 H-ras나 K-ras 세포의 경우에 는 에탄올 존재 하에서도 세포증식에는 특이한 영향이 없었 다. 이는 에탄올의 세포증식억제 작용이 ras 변이에 의한 세포 증식은 억제할 수 없으며, 또한 이는 알코올의 작용점이 Ras 단백질의 upstream에 존재하거나, 아니면 Ras단백질과는 상 관이 없을 것이란 것을 보여준다. 


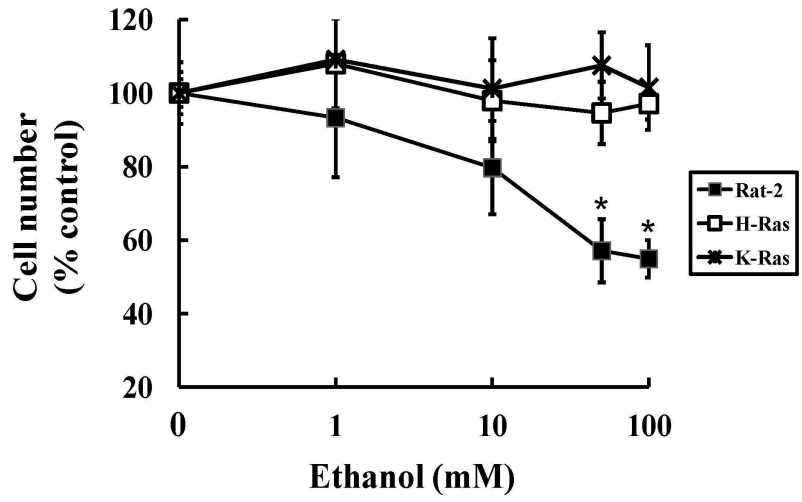

Fig. 2. Effect of ethanol on the proliferation of oncogenic $\mathrm{H}$-ras ${ }^{\mathrm{V} 12}$-transformed Rat-2 cells, oncogenic K-ras ${ }^{\mathrm{V} 12}$ transformed Rat-2 cells and parental Rat- 2 cells. Control Rat-2 and oncogenic Ras-transformed Rat- 2 cells $\left(4 \times 10^{4}\right.$ cell/well) were plated and treated with medium containing the indicated amount of ethanol for 3 days. The plates were tightly wrapped with parafilm and the media were refreshed every day. The number of cells was counted as described in the "Materials and Method" section. The data represent the mean number of cells from two experiments. Each experiment was performed in triplicate. The significance was determined by the ANOVA test $\left({ }^{*} p<0.01\right.$ vs. untreated control).

정상유방세포인 MCF-12A에 미세주입된 발암원성 $\mathrm{H}^{-}$ $\operatorname{Ras}^{\mathrm{V}}{ }^{12}$ 단백질에 의한 DNA 합성 유도에 대한 에탄올의 영향

발암원성 $\mathrm{ras}^{\mathrm{V} 12}$ 와 에탄올에 의한 세포증식억제 효과 사이 의 관계를 직접적으로 확인하기 위해 우리는 세포미세주사기 술을 적용했다. 정상유방세포인 MCF-12A세포의 세포주기를 정지시켜 DNA 합성을 억제시킨 후, 발암원성 발암원성 $\mathrm{H}-\mathrm{Ras}^{\mathrm{V} 12}$ 단백질을 세포 내로 미세주사하고, 주입된 Ras단백 질에 의한 세포증식을 위한 DNA합성에 대한 에탄올의 영향 을 알아보았다(Fig. 3). 본 연구팀에 미세주사된 발암원성 $\mathrm{H}-\mathrm{Ras}^{\mathrm{V} 12}$ 단백 질은 농도의존적으로 DNA 합성을 촉진한다고 보고하였다[13]. 대조군으로 미세주입된 Rat IgG를 주입한 세 포에서는 $15 \%$ 의 세포에서 DNA 합성이 일어났고, 발암원성 $\mathrm{Ras}^{\mathrm{V} 12}$ 단백질이 미세주입된 세포에서는 $66 \%$ 의 세포에서 DNA합성이 유도되었다. 에탄올을 전처리한 세포에 발암원성 H-Ras단백질를 미세주입한 세포에서는 $58.6 \%$ 세포에서 DNA 합성이 유도되었다. 따라서 에탄올에 의해 유의한 영향은 존 재하지 않았다. 이러한 결과는 에탄올에 의한 세포증식 억제 효과를 나타내는 작용점이 Ras단백질이 관여하는DNA 합성 유도 신호전달경로에서 Ras 단백질의 upstream에 존재하거 나, 아니면 Ras단백질과는 상관이 없을 것이란 것을 다시 한번 확인해준다.

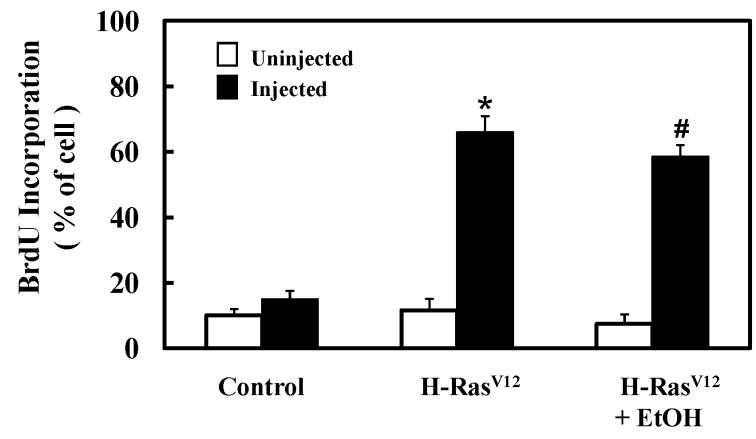

Fig. 3. Effect of ethanol on DNA synthesis induced by microinjection of oncogenic H-Ras ${ }^{\mathrm{V} 12}$ protein in human immortalized normal mammary MCF-12A cells. MCF-12A cells were grown on a coverslip before arresting the cell cycle. The cells were then injected with the oncogenic H-Ras ${ }^{\mathrm{V} 12}$ protein $(4 \mathrm{mg} / \mathrm{ml})$ containing rat $\mathrm{IgG}(5 \mathrm{mg} / \mathrm{ml})$. The cells were treated with ethanol $(100 \mathrm{mM}) 1 \mathrm{hr}$ before microinjection. After stabilization for $2 \mathrm{hr}$, cells were incubated with $\mathrm{BrdU}$ for $16 \mathrm{hr}$ at $37^{\circ} \mathrm{C}$. They were then processed for double-label indirect immunofluorescence as described in the "Materials and Method" section. An average of 167 control IgG-injected (range 152-187) cells, $156 \mathrm{H}-\mathrm{Ras}^{\mathrm{V} 12}$-injected (range 145-188) cells, and 186 $\mathrm{H}-\mathrm{Ras}^{\mathrm{V} 12}$-injected and ethanol-treated (range 154-195) cells were counted. The results shown are the mean number of cells from two independent experiments. Each experiment was performed in triplicate. The significance was determined by the ANOVA test $\left({ }^{*} p<0.05\right.$ vs. untreated and uninjected control; ${ }^{\#} p<0.05$ vs. ethanol-treated and uninjected control).

\section{에탄올의 세포증식 억제효과와 활성산소 형성과의 상관관계} 에 관한 연구

Ras단백질외에도 활성산소가 에탄올의 세포증식억제 효과 에 중요한 것으로 보고되어 왔다[10,15]. 우리는 다음으로 활성 산소가 에탄올에 의한 세포증식억제효과와 어떤 관계가 있는 지 알아보기 위해, 먼저 에탄올에 의한 활성산소의 형성을 조 사하였고, Ras 형질전환 Rat-2 세포에서의 활성산소 형성을 조사하였다(Fig. 4A). 에탄올에 의해 대조군인 Rat-2 세포에서 활성산소 생성이 증가하였다. Ras 형질전환 세포에서는 ROS 의 발생을 조사한 결과, 대조군에 비해 증가하였다. 그러나 에탄올에 의해 유의한 활성산소의 증가를 관찰할 수 없었다.

정상세포에서 에탄올에 의해 증가한 활성산소가 세포증식 억제를 유도하는지를 조사하기 위해 free radical trapping agent를 사용하여 에탄올의 세포증식억제효과에 대한 영향을 조사하였다. 사용한 활성산소 억제제로서 free radical scavenger 인 $N$-acetylcysteine (NAC), CYP2E1 inhibitor인 4-methylpyrazole (4-MP), lipid peroxidation inhibitor인 vita- 
(A)

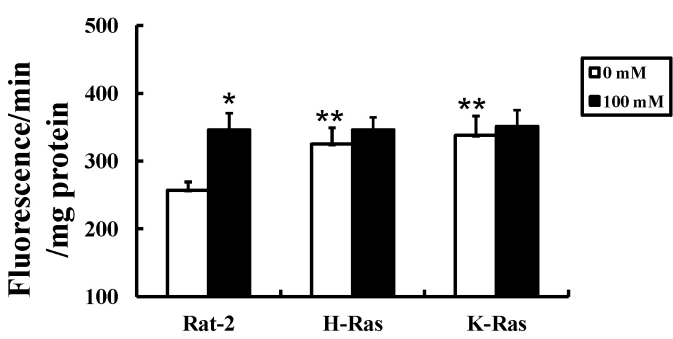

(B)

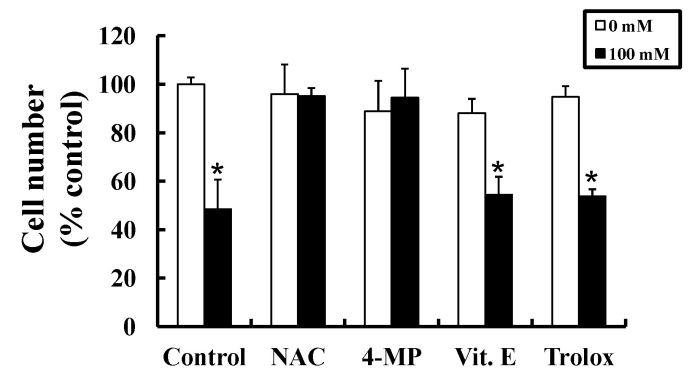

Fig. 4. Involvement of ROS in anti-proliferative effect of ethanol. (A) Rat-2, H-ras ${ }^{V 12}$-trnsformed Rat-2, and K-ras ${ }^{V 12}$-transformed Rat-2 cells were treated with $100 \mathrm{mM}$ ethanol for 3 days. Intracellular ROS levels were measured as described in the "Materials and Methods" section. (B) MCF-12A cells $\left(4 \times 10^{4}\right.$ cells/plate) were incubated with $\mathrm{N}$-acetylcysteine (NAC) (1 mM), 4-methylpyrazole (4-MP) $(1 \mathrm{mM})$, vitamin E (Vit. E) $(25 \mathrm{mM})$, and trolox $(0.2 \mathrm{mM})$ for $2 \mathrm{hr}$, and then treated with ethanol $(100$ $\mathrm{mM})$. The cells were incubated for 3 days and cell numbers were counted. The data represent the mean number of cells from two independent experiments. Each experiment was performed in triplicate. The significance was determined by the ANOVA test $\left({ }^{*} p<0.05\right.$ vs. untreated control; ${ }^{* *} p<0.05$ vs. untreated Rat-2 control cells).

$\min \mathrm{E}$ (Vit. E), soluble Vit. E인 trolox와 같은 항산화제를 사용 하였다. 항산화제를 MCF-12A세포에 전처리 후, 에탄올을 처 리하고 그 효과를 측정하였다(Fig. 4B). NAC와 4-MP는 효과 적으로 에탄올에 의한 세포증식 억제효과를 방해하였다. 그러 나 흥미롭게도 Vit. E와 그 유도체인 trolox는 에탄올에 의한 세포증식억제 작용에는 특이한 효과가 없었다. 즉 수용성 항 산화제인 NAC나 4-MP와 지용성 항산화제인 Vit. E계열간의 작용 차이는 에탄올에 의해 형성된 활성산소 중 세포내 수용 성 부위에 작용하는 것이 에탄올에 의한 세포증식 억제에 중 요할 것으로 사료된다. 이러한 결과는 활성산소 형성이 에탄 올에 의한 세포증식 억제효과에 중요한 역할을 하며, 활성산 소의 형성 부위에 따라 다르게 작용한다는 것을 알 수 있다.

\section{고 찰}

본 연구에서 우리는 에탄올의 세포증식 억제 효과가 정상
세포와 암세포에서 조사하여 차이가 있는 것을 알 수 있었다. 특히 ras 유전자 변이에 의한 발암원성에 의한 세포증식에는 에탄올이 세포증식이나 DNA합성을 방해하지 못 하는 것을 알 수 있었다. 이 결과는 에탄올의 세포증식억제 효과의 작용 점이 Ras단백질의 upstream이거나 독립적인 경로를 통하는 것으로 알 수 있다. 본 연구에서 사용한 세포 미세주사기술은 세포내 신호전달분자가 특정 세포 현상이나 호르몬과 같은 신호유발 인자에 관여하는지 여부를 직접적으로 보여주는 기 술이다. 세포미세주사기술을 통해 활성화된 발암원성 $\operatorname{Ras}^{\mathrm{V} 12}$ 단백질이 에탄올의 존재하에서도 DNA 합성을 정상적으로 유 도함을 알 수 있는데, 이 결과는 발암원성 $\mathrm{Ras}^{\mathrm{V} 12}$ 단백질의 작 용점이 에탄올에 의한 억제효과를 나타내는 작용점과 먼 곳에 존재하는 것으로 결론지을 수가 있다.

ras 암유전자가 관여하는 세포증식 신호전달경로는 잘 알려 져 있으나, 에탄올의 carcinogen 작용과의 관계는 아직 완전히 규명되지 않았다. 최근 에탄올의 장기 투여에 의해 간암조직 에서 $\mathrm{H}-\mathrm{ras}$ 의 변이를, 췌장암에서는 K-ras의 변이를 유도하는 것이 보고되었다[6,12]. 즉 에탄올에 의한 직접적인 $r a s$ 유전자 의 변이를 통해 암발생을 유도할 뿐 아니라, 본 연구결과에 의하면 변이된 $r a s$ 유전자에 의한 세포증식도 억제하지 못하 는 것을 알 수 있었다. 최근 Chavez 등[4]은 에탄올에 의해 간암 발생이 야기되며 정상적인 간세포의 증식은 억제하는 것이 쥐의 실험에서 보고하였다. 즉 정상세포의 세포증식은 에탄올에 의해 억제되었지만, 발암원성 ras 에 의해 형 질전환 세포는 에탄올에 대해 영향을 받지 않았다. 그러므로 동일 조 직에서 형질전환된 암세포는 에탄올 존재 여부와는 상관없이 지속적으로 세포증식이 진행되나, 그와는 반대로 정상세포는 세포증식과정을 멈출 것이다. 따라서 에탄올에 의한 세포증식 억제 효과는 정상세포에서는 작용하나 Ras 또는 기타 암유전 자의 변이에 의해 유도된 세포증식은 에탄올에 의해 세포증식 이 영향을 받지 않으므로 암세포의 증식을 간접적으로 도와주 는 결과를 초래하는 것으로 추정할 수 있다.

활성산소가 암세포의 증식을 유도하거나 암세포의 유지에 중요한 것은 잘 알려져 있다. 또한 활성산소는 어떤 조건이나 세포에서는 세포 노쇠와 세포사멸을 유도하는 것도 잘 알려져 있다. 이 상반된 활성산소의 영향의 기전은 생성되는 활성산 소의 양이나 종류에 따라 다르며 세포 종류나 환경의 차이 등에 의해서도 반응할 것으로 추정된다. Ras에 의한 암세포에 서 활성산소의 생성능이나 역할은 세포 종류와 Ras isoform에 따라 상반된 결과가 보고 되어 있다[23,26]. 본 실험에서는 Ras 에 의해 형 질전환된 Rat-2 세포의 경우에서는 활성산소 생성 이 증가된 것이 관찰되었다. 그러나 대조군 세포에서 관찰된 에탄올에 의한 활성산소의 생성이 이 Ras 형질전환세포에서 는 관찰되지 않았다. 따라서 Ras로 형질전환된 세포의 경우에 는 세포내 redox state의 변화가 야기되어 이미 세포가 높은 활성산소에 적응되어 증식되고 있기 때문에 에탄올에 의한 
세포증식 억제 효과가 작용하지 않는 것으로 사료되나, 정확 한 기전을 밝히기 위해서는 앞으로 추가적인 실험이 필요한 것으로 생각된다.

정상적인 세포증식은 EGF, IGF-1, 인슐린등과 같은 다양한 성장인자들이 유도하며 이러한 성장인자들의 세포증식 효과 를 에탄올이 억제하는 것이 알려져 있다. 에탄올에 의해 간세 포의 인슐린신호와 EGF신호 및 IGF-1신호에 의한 세포증식이 억제 되었고 $[7,22,30]$, 또한 본 연구팀은 인슐린에 의한 DNA 합성 유도를 에탄올이 억제하였고, 이는 에탄올에 의한 PI3-kinase 활성 억제와 관련이 있는 것을 보고하였다[28]. 그 러나 본 연구결과에서는 발암원성 $r a s$ 유전자에 의한 세포증 식은 에탄올이 억제하지 못하므로 에탄올에 의한 세포증식 억제 효과의 작용점은 ras 단백질 위에 존재하는 PI3-kinase의 작용을 억제하거나 또는 활성산소의 형성을 통해 발생하는 것으로 사료된다.

\section{감사의 글}

이 논문은 부산대학교 자유과제 학술연구비(2년)에 의하여 연구되었음.

\section{References}

1. Baan, R., Straif, K., Grosse, Y., Secretan, B., el Ghissassi, F., Bouvard, V., Altieri, A. and Cogliano, V. 2007. Carcinogenicity of alcoholic beverages. Lancet Oncol. 8, 292-293.

2. Boffetta, P. and Hashibe, M. 2006. Alcohol and cancer. Lancet Oncol. 7, 149-156.

3. Brennan, P., Lewis, S., Hashibe, M., Bell, D. A., Boffetta, P., Bouchardy, C., Caporaso, N., Chen, C., Coutelle, C., Diehl, S. R., Hayes, R. B. Olshan, A. F., Schwartz, S. M., Sturgis, E. M., Wei, Q. A., Zavras, I. and Benhamou, S. 2004. Pooled analysis of alcohol dehydrogenase genotypes and head and neck cancer: a HuGE review. Am J. Epidemiol. 159, 1-16.

4. Chavez, P. R., Lian, F., Chung, J., Liu, C. S., Paiva, A., Seitz, H. K. and Wang, X. D. 2011. Long-term ethanol consumption promotes hepatic tumorigenesis but impairs normal hepatocyte proliferation in rats. J. Nutr. 141, 1049-1055.

5. Chen, G., Colombo, L. L., Lopez, M. C. and Watson, R. R. 1996. Effect of ethanol and cocaine treatment of the immune system of v-Ha-ras-transgenic mice. Int. J. Immumopharmacd. 18, 251-258.

6. Crous-Bou, M., Porta, M., López, T., Jariod, M., Malats, N., Morales, E. Guarner, L., Rifà, J. and Carrato, A. 2009. Real FX; PANKRAS II Study Group. Lifetime history of alcohol consumption and K-ras mutations in pancreatic ductal adenocarcinoma. Environ. Mol. Mutagen. 50, 421-430.

7. Derdak, Z., Lang, C. H., Villegas, K. A., Tong, M. N., Mark, M., de la Monte, S. M. and Wands, J. R. 2011. Activation of p53 enhances apoptosis and insulin resistance in a rat model of alcoholic liver disease. J. Hepatol. 54, 164-172.

8. Fan, J., Edsen-Moore, M. R., Turner, L. E., Cook, R. T., Legge, K. L., Waldschmidt, T. J. and Schlueter, A. J. 2011. Mechanisms by which chronic ethanol feeding limits the ability of dendritic cells to stimulate T-cell proliferation. Alcohol Clin. Exp. Res. 35, 47-59.

9. Hipp, J. A., Hipp, J. D., Atala, A. and Soker, S. 2010. Ethanol alters the osteogenic differentiation of amniotic fluid-derived stem cells. Alcohol Clin. Exp. Res. 34, 1714-1722.

10. Hoek, J. B. and Pastorino, J. G. 2002. Ethanol, oxidative stress, and cytokine induced liver cell injury. Alcohol 27, 63-68.

11. International Agency for Research on Cancer. 1988. Alcohol drinking. IARC monographs on the evaluation of carcinogenic risks to humans. Vol. 44, Lyon: IARC.

12. Jeannot, E., Pogribny, I. P., Beland, F. A. and Rusyn, I. 2011. Chronic administration of ethanol leads to an increased incidence of hepatocellular adenoma by promoting H-ras-mutated cells. Cancer Lett. 301, 161-167.

13. Jhun, B. H., Meinkoth, J. M., Leitner, J. W., Draznin, B. and Olefsky, J. M. 1994. Insulin and insulin-like growth factor-I signal transduction requires p21ras. J. Biol. Chem 269, 5699-5704.

14. LeBel, C. P., Ischiropoulos, H. and Bondy, S. C. 1992. Evaluation of the probe $2^{\prime}, 7^{\prime}$-dichlorofluorescin as an indicator of reactive oxygen species formation and oxidative stress. Chem Res. Toxicol. 5, 227-231.

15. Molina, P. E., Hoek, H. B., Nelson, S., Guidot, D. M., Lang, C. H., Wands, J. R. and Crawford, J. M. 2003. Mechanisms of alcohol induced tissue injury. Alcohol Clin. Exp. Res. 27, 563-575.

16. Morris, S. A., Eaves, D. W., Smith, A. R. and Nixon, K. 2010. Alcohol inhibition of neurogenesis: a mechanism of hippocampal neurodegeneration in an adolescent alcohol abuse model. Hippocampus 20, 596-607.

17. Morrow, D., Cullen, J. P., Liu, W., Cahill, P. A. and Redmond, E. M. 2010. Alcohol inhibits smooth muscle cell proliferation via regulation of the Notch signaling pathway. Arterioscler. Thromb. Vasc. Biol. 30, 2597-2603.

18. Ness, K. J., Fan, J., Wilke, W. W., Coleman, R. A., Cook, R. T. and Schlueter, A. J. 2008. Chronic ethanol consumption decreases murine Langerhans cell numbers and delays migration of Langerhans cells as well as dermal dendritic cells. Alcohol Cin. Exp. Res. 2, 657-668.

19. Oh, M. J., van Agthoven, T., Choi, J. E., Jeong, Y. J., Chung, Y. H., Kim, C. M. and Jhun, B. H. 2008. BCAR3 regulates EGF-induced DNA synthesis in normal human breast MCF-12A cells. Biochem Biophys. Res. Commun. 375, 430-434.

20. Pylayeva-Gupta, Y., Grabocka, E. and Bar-Sagi, D. 2011. RAS oncogenes: weaving a tumorigenic web. Nat. Rev. Cancer 11, 761-774.

21. Rehm, J., Room, R., Monteiro, M., Gmel, G., Graham, K., Rehn, N., Sempos, C. T., Frick, U. and Jernigan, D. 2004. Alcohol use. pp. 960-1108, In Ezzati, M., A. Lopez, A. Rodgers, and C. Murray (eds.), Comparative Quantification of Health Risks. Global and Regional Burden of Disease 
Attributable to Selected Major Risk Factors. WHO, Geneva.

22. Resnicoff, M., Sell, C., Ambrose, D., Baserga, R. and Rubin, R. 1993. Ethanol inhibits the autophosphorylation of the insulin-like growth factor 1 (IGF-1) receptor and IGF-1-mediated proliferation of 3T3 cells. J. Biol. Chem 268, 21777-21782.

23. Trachootham, D., Zhou, Y., Zhang, H., Demizu, Y., Chen, Z., Pelicano, H., Chiao, P. J., Achanta, G., Arlinghaus, R. B., Liu, J. and Huang, P. 2006. Selective killing of oncogenically transformed cells through a ROS-mediated mechanism by beta-phenylethyl isothiocyanate. Cancer Cell. 10, 241-252.

24. Wands, J. R., Carter, E. A., Bucher, N. L. R. and Isselbacher, K. J. 1980. Effect of acute and chronic ethanol intoxication on hepatic regeneration. Adv. Exp. Med Biol. 132, 663-670.

25. Wang, H., Zhou, H., Chervenak, R., Moscatello, K. M., Brunson, L. E. and Chervenak, D. C. 2009. Wolcott RM. Ethanol exhibits specificity in its effects on differentiation of hematopoietic progenitors. Cell Immunol. 255, 1-7.

26. Weinberg, F., Hamanaka, R., Wheaton, W. W., Weinberg, S., Joseph, J., Lopez, M., Kalyanaraman, B., Mutlu, G. M., Budinger, G. R. and Chandel, N. S. 2010. Mitochondrial metabolism and ROS generation are essential for Kras-mediated tumorigenicity. Proc. Natl. Acad Sci. USA 107, 87888793.

27. Wong, N. A., Rae, F., Simpson, K. J., Murray, G. D. and Harrison, D. J. 2000. Genetic polymorphisms of cytochrome p4502E1 and susceptibility to alcoholic liver disease and hepatocellular carcinoma in a white population: a study and literature review, including meta-analysis. Mol. Pathol. 53, 88-93.

28. Yi, S. J. and Jhun, B. H. 2004. Ethanol impairs insulin's actions through phosphatidylinositol 3-kinase. J. Med Food7, 24-30.

29. Yokoyama, Y., Nagino, M. and Nimura, Y. 2007. Mechanism of impaired hepatic regeneration in cholestatic liver. $J$. Hepatobiliary Pancreat. Surg. 14, 159-166.

30. Zhang, B. H., Ho, V. and Farrell, G. C. 2001. Specific involvement of $G$ (alphai2) with epidermal growth factor receptor signaling in rat hepatocytes, and the inhibitory effect of chronic ethanol. Biochem Pharmacol. 61, 1021-1027.

\section{초록 : 정상세포와 암세포의 증식 억제에 대한 에탄올의 영향}

오명주 ${ }^{2} \cdot$ 김지현 ${ }^{2} \cdot$ 박수현 ${ }^{2} \cdot$ 정영화 $^{2} \cdot$ 왕쿤 $^{3} \cdot$ 조병욱 $^{3} \cdot{\text { 전병학 }{ }^{2}}^{\star}$

( ${ }^{1}$ 식품의약청 임상시험관리부, ${ }^{2}$ 부산대학교 나노과학기술대학 나노메디컬공학과, ${ }^{3}$ 부산대학교 생명자원과 학대학 동물자원학과)

에탄올은 사람에 대한 발암물질로 잘 알려져 있다. 또한 여러 조직이나 세포에서의 에탄올에 의한 세포증식 억제효과도 잘 알려져 있다. 본 연구에서는 여러 암세포에서 에탄올에 의한 세포증식억제 효과를 조사하였는데 특히 발암원성 ras로 형질전환되거나 미세주입된 세포에서의 영향을 조사하였다. 에탄올은 여러 정상세포들의 증식을 억제하였다. 반면에 여러 암세포나 발암원성 Ras에 의한 세포증식은 억제하지 못 하였다. 또한 발암원성 단백질의 세포내 미세주사에 의한 DNA합성 유도도 에탄올에 의해 억제 되지 않았다. 이러한 에탄올의 세포증식 억제 효과는 $N$-acetylcysteine이나 4-methylpyrazole과 같은 항산화제에 의해 제거되었다. 이러한 실험 결과는 에 탄올에 의한 세포증식억제 효과는 Ras단백질의 upstream에 있거나 또는 Ras와 독립적으로 작용하며, 활성산소 형성과 밀접한 관계가 있다는 것을 알려준다. 